\title{
PENK Gene Product
}

National Cancer Institute

\section{Source}

National Cancer Institute. PENK Gene Product. NCI Thesaurus. Code C126495.

A protein encoded by the PENK gene. 